\title{
Pengaruh Model Problem Based Learning Berbasis Potensi Lokal pada Pembelajaran Biologi terhadap Kemampuan Literasi Sains Siswa Kelas X SMA Negeri 1 Cepogo
}

\author{
The Influence of Problem-Based Learning Based on Localities Models \\ at Biology Lessons Toward Scientific Literacy of Students \\ of Grade X SMA Negeri 1 Cepogo
}

\author{
Amytia Putri ${ }^{a}$, Suciati $^{\text {b }}$, Murni Ramli ${ }^{\mathrm{c}}$ \\ ${ }^{a}$ Pendidikan Biologi FKIP UNS, Email: amytia.putri@gmail.com \\ ${ }^{\mathrm{b}}$ Pendidikan Biologi FKIP UNS, Email: suciati.sudarisman@yahoo.com \\ ${ }^{\mathrm{c}}$ Pendidikan Biologi FKIP UNS, Email: moernier@gmail.com
}

Diterima 20 Agustus 2014, disetujui 20 September 2014

\begin{abstract}
Purpose of this research is to know the influence of of Problem Based Learning based on localities models toward scientific literacy of students of grade $\mathrm{X}$. The research was a quasy experimental research used posttest only non-equvalent control groups. Population of the reserach was the students of grade $\mathrm{X}$ in the second semester of SMA N 1 Cepogo in the academic year 2013/2014. Sampling technique was cluster sampling method. Collected data was connucted by test and non test method. The test for measuring scientific literacy was a five essay test, which consist of three aspects, namely: to identify scientific issues, to explain phenomena scientifically, and to use scientific evidence. The non test method were observation, and documentation. Hypothesis test were analysed by t-test using SPSS version 16 . The results of the research were received H1 and rejected H0. It means there was a difference of scientific literacy between control class (conventional models) and experiment class using Problem Based Learning based on localities. The average score of scientific literacy in experimental class was 48,47 and score of control class was 26,95 . It was also found that the highetst average of scintific literacy in the experimental class was aspect to use scientific evidence, while the lowest one was to identify scientific issues. The conclusion of the research was Problem Based Learning based on localities models significantly influenced the scientific literacy of grade X students SMA N 1 Cepogo.
\end{abstract}

Key Words: Problem Based Learning, scientific literacy, based on localities

\section{Pendahuluan}

Sains merupakan kunci dari perkembangan Ilmu Pengetahuan dan Teknologi (IPTEK), sehingga tidak dipungkiri lagi sains telah menjadi aspek yang sangat penting dalam berbagai segi kehidupan manusia. Upaya mengimbangi laju perkembangan IPTEK juga menuntut manusia terus menyesuaikan diri dalam segala aspek, tidak terkecuali dalam hal pendidikan (Liu, 2009). Sementara itu menurut OECD (Organisation for Economic Co-Operation and Development), dampak dari kemajuan IPTEK menimbulkan permasalahan kehidupan manusia yang kompleks, sehingga menuntut sumber daya manusia (SDM) yang memiliki wawasan saintifik untuk memecahkan masalah tersebut. Preczewski, et. al (2009) menambahkan bahwa proses mencetak SDM dengan 
kapasitas berwawasan saintifik ditempuh melalui proses pendidikan yang mengedepankan tidak saja pengetahuan sains, tetapi juga kepekaan dan kemampuan menjelaskan fenomena sehari-hari dengan pengetahuan sains yang dimiliki, dan memecahkan masalah melalui pendekatan saintifik. Oleh karena itu, proses pendidikan diharapkan mampu menghasilkan manusia yang sadar terhadap sains, atau disebut memiliki literasi sains.

PISA mendefinisikan literasi sains sebagai pengetahuan tentang sains individu yang digunakan untuk mengidentifikasi pertanyaan, memperoleh pengetahuan baru, menjelaskan fenomena, dan untuk membuat kesimpulan tentang isu ilmiah berdasarkan bukti-bukti ilmiah; mengetahui karakteristik sains sebagai penyelidikan ilmiah; menyadari bahwa sains dan teknologi membentuk lingkungan material, intelektual dan budaya; serta kesediaan untuk terlibat dalam isu-isu terkait sains sebagai manusia yang reflektif (OECD, 2009). Secara berkala PISA telah mengukur kemampuan literasi sains siswa berusia 15 tahun di berbagai negara.

Idealnya, setiap individu harus memiliki literasi sains yang tinggi untuk dapat mengimbangi laju perkembangan IPTEK, sehingga dapat menyelesaikan berbagai macam masalah yang ditimbulkan seiring dengan perkembangan jaman (Dani, 2009).

Namun, kenyataan di lapangan menunjukkan bahwa kemampuan literasi sains siswa Indonesia masih rendah. Berdasarkan data PISA dari tahun ke tahun posisi Indonesia nyaris menjadi juru kunci. Pada tahun 2009 skor yang diperoleh adalah 383, dan menempatkan Indonesia pada peringkat 60 dari 65 negara (Fleischman, 2010). Menurut Toharudin (2011: 16), dengan capaian tersebut rata-rata kemampuan sains peserta didik Indonesia terbatas pada kemampuan mengenali sejumlah fakta dasar, tetapi mereka belum mampu untuk mengkomunikasikan dan mengaitkan kemampuan itu dengan berbagai topik sains, apalagi menerapkan konsepkonsep yang kompleks dan abstrak dalam kehidupan siswa sehari-hari.

Firman dalam Herdiani (2013) menjelaskan bahwa penyebab rendahnya literasi sains siswa di Indonesia disebabkan oleh pembelajaran yang bersifat tekstual dan kurang kontekstual. Guru lebih banyak mentransfer pengetahuan yang dimilikinya kepada siswa, tanpa memberi kesempatan kepada siswa untuk membangun sendiri pengetahuan yang ada di benak mereka. Hal ini relevan dengan hasil penelitian Suastra (2005), bahwa pembelajaran 
sains yang terjadi saat ini kurang memanfaatkan lingkungan di sekitar siswa, sehingga siswa kesulitan untuk menghubungkan konsep sains yang dimiliki dengan kehidupan sehari-hari. Kondisi rendahnya kemampuan literasi sains siswa Indonesia apabila tidak segera diatasi, akan berdampak pada rendahnya mutu SDM dan akibat yang lebih besar akan menghambat kemajuan IPTEK di Indonesia.

Solusi yang dianggap sesuai untuk mengatasi masalah di atas adalah dengan menerapkan sebuah model pembelajaran Biologi yang mampu mendorong siswa membangun konsep mereka sendiri, melalui pembelajaran dengan pendekatan ilmiah (scientific approach), bersifat kontekstual, melibatkan aspek-aspek kehidupan sehari-hari siswa, dan memanfaatkan alam sekitar, lingkungan dan potensi lokal di mana siswa berada, sehingga dapat meningkatkan kemampuan literasi sains siswa (Suastra, 2010).

\section{Problem Based Learning (PBL)} merupakan pembelajaran yang membebaskan siswa untuk memilih penelitiannya sendiri sehingga memungkinkan mereka untuk mengaitkannya dengan fenomena nyata dan membangun pemahaman dengan konsep yang mereka dapatkan dari fenomena tersebut. $P B L$ juga melatih siswa untuk belajar menjadi "orang dewasa" yang mengambil peran-peran penting dalam masyarakat untuk mengatasi berbagai permasalahan yang dihadapi di berbagai situasi kehidupan nyata (Arends, 2008: 43).

Materi yang terdapat dalam pembelajaran sains sangat dekat dengan kehidupan sehari-hari, oleh karena itu pembelajaran sains seharusnya bersifat kontekstual dan memanfaatkan lingkungan sekitar siswa, sehingga dapat lebih mudah dipahami. Hal ini sejalan dengan UU Republik Indonesia No. 20 tahun 2003 tentang Sistem Pendidikan Nasional pada BAB X pasal 36 ayat (3) butir d yang mengharuskan setiap sekolah untuk menerapkan model pendidikan berbasis keunggulan/potensi lokal yang terdapat pada masing-masing daerah sebagai sarana untuk lebih mengenalkan siswa pada lingkungannya, sehingga memiliki keterampilan yang sesuai dengan potensi lokal yang dimiliki daerahnya.

Cepogo merupakan daerah dataran tinggi dengan ketinggian 800 meter di atas permukaan laut. Kecamatan yang merupakan bagian dari Kabupaten Boyolali ini berjarak $11 \mathrm{~km}$ dari lereng Gunung Merapi, sehingga mengakibatkan tanah di daerah ini sangat cocok untuk ditanami sayur-sayuran. Kondisi wilayah Cepogo memungkinkan untuk diangkat sebagai isu kontekstual dalam 
pembelajaran Biologi, sehingga potensi lokal ini cocok untuk dikembangkan menjadi substansi pembelajaran berbasis potensi sumber daya alam.

Penelitian bertujuan untuk mengetahui ada tidaknya pengaruh model Problem Based Learning (PBL) berbasis potensi lokal terhadap kemampuan literasi sains siswa kelas X SMA N 1 Cepogo.

\section{Metode}

Penelitian termasuk quasy experiment dengan pendekatan kuantitatif. Desain penelitian adalah posttest only with nonequivalent group dengan menggunakan kelas eksperimen (penerapan model PBL berbasis potensi lokal) dan kelas kontrol (pembelajaran konvensional).

Populasi dalam penelitian ini adalah seluruh peserta didik kelas $\mathrm{X}$ Semester Genap di SMA Negeri 1 Cepogo Tahun Pelajaran 2013/2014 dengan jumlah 117 siswa. Teknik pengambilan sampel dengan cluster sampling, sehingga terpilih kelas $\mathrm{X} 4$ sebagai kelas eksperimen dan kelas X3 sebagai kelas kontrol.

Variabel terikat pada penelitian ini adalah kemampuan literasi sains yag terdiri dari tiga aspek, yaitu mengidentifikasi isu ilmiah, menjelaskan fenomena secara ilmiah, dan menggunakan bukti ilmiah. Variabel bebasnya adalah model pembelajaran $P B L$ berbasis potensi lokal di kelas eksperimen dan pembelajaran konvensional di kelas kontrol. Data dianalisis menggunakan uji KolmogorovSmirnov untuk menguji normalitas, uji Levene's untuk menguji homogentias, dan uji-t untuk menguji kesetimbangan. Metode pengumpulan data yang digunakan dalam penelitian adalah tes, dokumentasi, dan observasi. Tes yang digunakan merupakan tes uraian yang terdiri dari lima soal, yang terdiri dari satu soal untuk menguji aspek mengidentifikasi isu ilmiah, dua soal untuk menguji aspek menjelaskan fenomena secara ilmiah, dan dua soal untuk menguji aspek menggunakan bukti ilmiah. Dokumentasi adalah nilai ulangan harian semester gasal digunakan untuk uji keseimbangan sampel. Lembar observasi digunakan untuk mengontrol keterlaksanaan sintaks model pembelajaran $P B L$ berbasis potensi lokal. Observasi juga dilakukan pada proses pembelajaran melalui lembar observasi sikap dan keterampilan.

Validasi Instrumen penelitian dengan uji validitas isi dan konstruk oleh ahli. 


\section{Hasil Pembahasan}

Data penelitian berupa tes kemampuan literasi sains, yang meliputi 3 aspek yaitu, mengidentifikasi isu ilmiah, menjelaskan fenomena secara ilmiah, dan menggunakan bukti ilmiah. Data postes dianalisis dengan uji-t untuk mengetahui pengaruh model $P B L$ berbasis potensi lokal terhadap kemampuan literasi sains.

Hasil analisis statistik pengaruh model $P B L$ berbasis potensi lokal terhadap peningkatan kemampuan literasi sains disajikan pada Tabel 1.

Tabel 1. Hasil Uji Hipotesis Pengaruh Model PBL berbasis potensi lokal terhadap Kemampuan Literasi Sains

\begin{tabular}{lccl}
\hline Variabel & df & Sig & $\begin{array}{l}\text { Keputusan } \\
\text { Uji }\end{array}$ \\
\hline $\begin{array}{l}\text { Kemampuan } \\
\text { Literasi Sains }\end{array}$ & 41 & 0.000 & $\mathrm{H}_{0}$ ditolak \\
\hline
\end{tabular}

Berdasarkan hasil perhitungan

uji-t diketahui bahwa $\mathrm{H}_{0}$ ditolak, artinya model $P B L$ berbasis potensi lokal berpengaruh terhadap peningkatan kemampuan literasi sains siswa SMA Negeri 1 Cepogo. Perbandingan rata-rata nilai kemampuan literasi sains siswa kelas kontrol dengan kelas eksperimen disajikan pada Gambar 1.

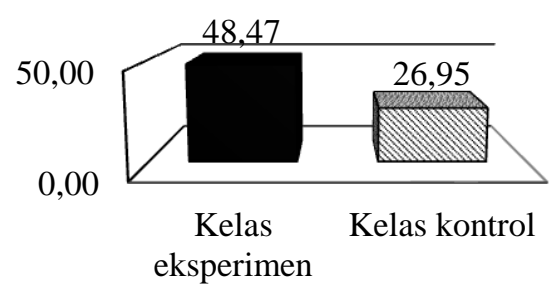

Gambar 1. Perbandingan Rata-Rata Nilai Kemampuan Literasi Sains Siswa Kelas Kontrol dan Kelas Eksperimen

Rata-rata nilai kemampuan literasi sains siswa yang diperoleh kelas eksperimen $(48,47)$ dengan penerapan model $P B L$ berbasis potensi lokal lebih tinggi dibandingkan nilai kelas kontrol $(26,95)$ yang menggunakan model pembelajaran konvensional. Hal ini diduga karena pada pembelajaran dengan model $P B L$ berbasis potensi lokal dapat melatih dan mengoptimalkan kemampuan literasi sains pada materi Manusia dan Lingkungan pada aspek mengidentifikasi isu ilmiah, menjelaskan fenomena secara ilmiah, serta menggunakan bukti ilmiah.

Hasil tes kemampuan literasi sains kelas kontrol dengan kelas eksperimen pada setiap aspek disajikan pada Gambar 2.

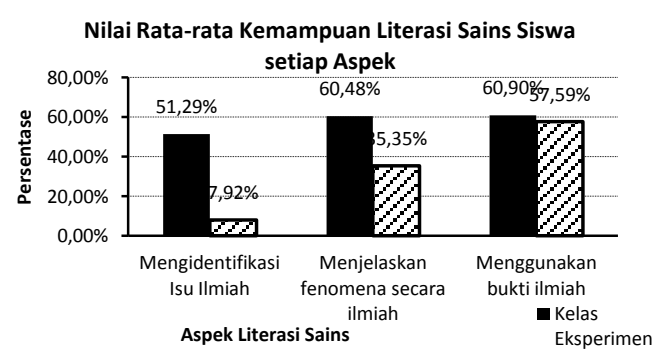

Gambar 2. Perbandingan Rata-Rata Nilai Kemampuan Literasi Sains Setiap Aspek

\section{Aspek Mengidentifikasi Isu Ilmiah}

Berdasarkan Gambar 2 dapat diketahui persentase kemampuan mengidentifikasi isu ilmiah siswa pada 
kelas eksperimen lebih tinggi dibandingkan kelas kontrol. Fakta ini diduga karena sintaks tahap pertama dan kedua $P B L$ yang dilakukan pada kelas eksperimen, yaitu memberikan orientasi tentang permasalahannya kepada siswa serta mengorganisasikan siswa untuk belajar.

Melalui model $P B L$ siswa
diorientasikan pada masalah yang bersifat ill-structured. Berdasarkan penelitian yang dilakukan oleh Yew \& Schmidt (2009), masalah yang bersifat ill-structured memiliki penyelesaian tidak hanya dari satu sisi saja, melainkan dari berbagai sudut pandang dan lebih dari satu cara pemecahan masalah, sehingga dapat membantu siswa untuk mengoptimalkan kemampuan problem solving yang mereka miliki.

Pada saat pembelajaran di kelas, siswa diorientasikan pada masalah melalui wacana yang diberikan oleh guru mengenai permasalahan lingkungan yang terjadi di sekitar mereka. Permasalahan yang disajikan oleh guru sejalan dengan penelitian Akcay (2009) bahwa guru dapat mendesain masalah yang bersifat ill-structured berdasarkan kurikulum, karakteristik siswa dan lingkungan di sekitar kehidupan siswa, serta masalah yang ada pada dunia nyata dalam konteks yang lebih luas. Permasalahan yang disajikan oleh guru dapat memotivasi siswa untuk belajar.

Masalah yang diberikan kepada siswa adalah studi kasus tentang daerah Cepogo yang merupakan daerah pertanian sayuran dan kasus penambangan pasir dari Gunung Merapi. Ada lima masalah yang diangkat, yaitu masalah penggunaan pestisida kimia dan pupuk kimia oleh para petani, penambangan pasir oleh masyarkat sekitar, penggunaan deterjen, serta penggunaan kendaraan bermotor.

Sejalan dengan penelitian Santoso (2010) dan Mumpuni (2013), kasuskasus dan permasalahan yang diangkat dari daerah sekitar kehidupan siswa akan memotivasi siswa untuk belajar, karena pembelajaran bersifat kontekstual dan sesuai dengan apa yang dialami siswa secara langsung, sehingga dapat menjadikan pembelajaran lebih bermakna. Selain itu, pembelajaran berbasis potensi lokal akan melatih siswa untuk lebih peduli pada lingkungannya, sehingga dapat melatih mereka untuk lebih bijak dalam memberdayakan potensi yang terdapat di daerah mereka masing-masing. Melalui masalah yang diberikan, siswa diminta untuk mencari solusi tentang kasus-kasus yang terjadi di sekitar mereka.

Selama pembelajaran, guru hanya bertindak sebagai fasilitator. Pada tahap 
mengorientasikan siswa pada masalah, guru membimbing siswa untuk membuat rumusan masalah sesuai dengan wacana yang didapat masing-masing kelompok. Rumusan masalah yang dibuat siswa kemudian divalidasi oleh guru dengan menggunakan lembar validasi yang telah dibuat sebelumnya untuk mengecek kesesuaian rumusan masalah yang dibuat siswa dengan tujuan yang diaharapkan dalam pembelajaran.

Menurut penelitian Maurer \& Neuhold (2012), masalah yang disajikan dapat merangsang siswa untuk mengidentifikasi berbagai macam pertanyaan yang dapat diajukan sebagai rumusan masalah, sehingga siswa dapat mengenali pertanyaan-pertanyaan yang mungkin untuk diteruskan sebagai penyelidikan secara ilmiah. Hal ini menyebabkan aspek mengidentifikasi isu ilmiah dapat dikembangkan secara optimal.

Tahap kedua model $P B L$ adalah mengorganisasi siswa untuk belajar. Tahap ini juga berlangsung pada pertemuan pertama. Guru membimbing siswa untuk mengidentifikasi permasalahan lingkungan yang diterima oleh tiap-tiap kelompok dengan cara membuat rumusan masalah, hipotesis, tujuan dari penyelidikan, dan bagaimana cara mereka mendapatkan data. Siswa dibekali LKS untuk menuliskan rancangan penyelidikan yang akan mereka lakukan. Selain LKS, siswa juga diberi logbook yang harus diisi setiap siswa melakukan kegiatan penyelidikan.

Pada saat membuat rancangan penyelidikan, siswa harus mengetahui hal apa saja yang akan mereka lakukan dalam penyelidikan, bagaimana cara mereka mendapatkan data, serta informasi apa saja yang mereka butuhkan sebelumnya untuk mendapatkan data. Sejalan dengan penelitian Hung et. al (2008), pada saat membuat rancangan penyelidikan, siswa menyusun hipotesis dengan cara mengorganisasikan terlebih dahulu konsep-konsep apa saja yang telah mereka ketahui sebelumnya berkaitan dengan masalah yang disajikan, apa yang ingin mereka ketahui, dan bagaimana cara mereka untuk mengetahui lebih jauh tentang masalah yang mereka hadapi serta solusi dari permasalahan tersebut. Hal ini dapat melatih siswa untuk meningkatkan aspek mengidentifikasi isu ilmiah dengan cara mengenali fitur kata kunci dari penyelidikan yang akan mereka lakukan, seperti variabel apa yang harus diukur atau dikendalikan, informasi apa yang diperlukan dan tindakan apa saja yang harus diambil sehingga data dapat terkumpul. 
2. Aspek Menjelaskan Fenomena seccara Ilmiah

Berdasarkan Gambar 2 dapat diketahui persentase kemampuan menjelaskan fenomena ilmiah siswa pada kelas eksperimen lebih tinggi dibandingkan kelas kontrol. Hal tersebut didukung oleh sintaks tahap kedua dan ketiga $P B L$, yaitu mengorganisasi siswa untuk belajar serta membantu investigasi mandiri dan kelompok.

Seperti yang telah dijelaskan sebelumnya bahwa pada tahap mengorganisasi siswa untuk belajar, siswa dituntut untuk membuat rancangan penyelidikan melalui LKS. Selain rumusan masalah, tujuan, dan hipotesis, di dalam LKS juga terdapat "Need to Know Sheet" yang dapat membantu siswa mengorganisasikan pegetahuan awal. Lembar "Need to Know Sheet" berisi "Apa yang Telah Kamu Ketahui" yang harus dijawab siswa mengenai konsep yang telah diketahui oleh siswa sebelumnya mengenai permasalahan yang ada dalam wacana, "Apa yang ingin Kати Ketahui" yang merupakan tujuan dari penyelidikan yang akan dilakukan siswa, serta "Apa yang Harus Kamu Lakukan" yang merupakan cara siswa untuk mencari solusi dari permasalahan, cara mendapatkan data, dan hal-hal yang mereka butuhkan selama penelitian.
Berdasarkan "Need to Know Sheet" yang dibuat oleh siswa selama pembelajaan terlihat bahwa pengetahuan awal siswa hanya sebatas pestisida dapat merusak lingkungan, namun mereka belum dapat menjelaskan sejauh mana kerusakan yang terjadi dan mengapa dapat terjadi. Maka dari itu siswa ingin mengetahui dampak dari penggunaan pestisida secara berlebihan terhadap lingkungan dan solusi yang dapat digunakan untuk mengatasi permasalahan tersebut dengan cara melakukan wawancara kepada petani sekitar serta kajian literatur. Siswa menyusun daftar pertanyaan yang akan mereka gunakan untuk wawancara kepada petani dan mencari informasi di internet, buku, dan sumber-sumber lain sehingga data dapat terkumpul.

Lembar "Need to Know Sheet" akan membantu siswa untuk menghubungkan konsep-konsep sains awal yang telah mereka ketahui sebelumnya dengan hal yang harus mereka lakukan sehingga dapat terkumpul informasi baru. Penyesuaian antara konsep lama dengan informasi baru yang mereka dapatkan relevan dengan teori belajar Ausubel dalam Dahar (2011; 95), yang menyatakan bahwa belajar bermakna merupakan suatu proses mengaitkan informasi baru pada konsep-konsep relevan yang 
terdapat dalam struktur kognitif seseorang.

Selain itu, menurut penelitian Yew et. al (2010), membuat rancangan penyelidikan akan membantu siswa mengingat kembali konsep yang telah mereka miliki terkait dengan permasalahan yang dihadapi, sehingga siswa akan memilih konsep sains yang tepat dan sesuai dengan permasalahan tersebut. Hal ini akan mengoptimalkan aspek menjelaskan fenomena ilmiah, yaitu menggunakan pengetahuan sains yang tepat dalam berbagai situasi.

Tahap ketiga model $P B L$ adalah membantu investigasi mandiri dan kelompok. Tahap ini berlangsung pada pertemuan kedua selama dua jam pelajaran dan dilanjutkan di luar jam pelajaran. Guru membantu siswa untuk mendapatkan informasi yang tepat, melaksanakan eksperimen, dan mencari penjelasan serta solusi dari permasalahan yang dihadapi. Penyelidikan dan pembagian kerja tiap kelompok berbedabeda, tergantung dari perencanaan yang telah dibuat oleh tiap kelompok, misalkan wawancara, praktikum, studi literatur, dan pengamatan langsung. Setiap kelompok dibekali logbook yang harus mereka isi sesuai dengan kegiatan yang dilakukan oleh masing-masing kelompok, siapa saja yang terlibat dalam kegiatan tersebut, serta hasil apa yang mereka dapatkan. Fungsi logbook adalah untuk memudahkan guru memantau kegiatan penyelidikan yang dilakukan siswa, terutama apabila penyelidikan berlangsung di luar jam pelajaran.

$$
\text { Kegiatan investigasi yang }
$$
dilakukan siswa sejalan dengan teori belajar penemuan oleh Bruner dalam Arends (2008), yaitu pembelajaran seharusnya ditekankan pada pemecahan masalah dan penyelidikan. Siswa didorong untuk mendapatkan berbagai macam infomasi yang mereka butuhkan melalui pengamatan sendiri sehingga menemukan solusi dari permasalahan.

Kegiatan investigasi dapat memberikan kesempatan kepada siswa untuk mendapatkan pengalaman nyata tentang fenomena alam sebagai dasar pembelajaran kontekstual. Sejalan dengan penelitian Hmelo \& Silver (2004), kegiatan investigasi dapat memacu siswa mengonstruk pengetahuan mereka sendiri dengan cara mengaplikasikan pengetahuan yang telah mereka miliki sebelumnya ke dalam berbagai situasi permasalahan nyata. Chin \& Chia (2005) menambahkan bahwa kegiatan investigasi yang dilakukan siswa dapat mempersiapkan siswa lebih baik untuk menghadapi berbagai tantangan permasalahan hidup di dunia nyata, karena siswa dapat menghubungkan berbagai konsep sains 
yang telah dimiliki untuk memecahkan masalah yang ditemui. Hal tersebut dapat mengoptimalkan tercapainya aspek menjelaskan fenomena secara ilmiah, yaitu siswa dapat menguasai konsep sains dan mengaplikasikannya dalam berbagai situasi yang tepat, mampu menjelaskan fenomena secara ilmiah yang mereka temui dalam kehidupan sehari-hari dan memprediksi perubahan, serta mengidentifikasi deskripsi, penjelasan dan prediksi yang tepat.

\section{Aspek Menggunakan Bukti Ilmiah}

Berdasarkan Gambar 2 dapat diketahui persentase kemampuan menggunakan bukti ilmiah siswa pada kelas eksperimen lebih tinggi dibandingkan kelas kontrol. Tingginya aspek menggunakan bukti ilmiah pada kelas eksperimen dibandingkan dengan kelas kontrol didukung oleh pembelajaran dengan menggunakan $P B L$ pada tahap ketiga, keempat, dan kelima.

Tahap ketiga model $P B L$ adalah membantu investigasi mandiri dan kelompok. Seperti yang telah dijelaskan sebelumnya bahwa kegiatan penyelidikan siswa dilakukan melalui berbagai macam cara. Siswa berusaha untuk mengumpulkan informasi dari berbagai sumber, serta bukti sebanyak mungkin untuk dapat menemukan solusi dari permasalahan yang mereka temui. Maurer \& Neuhoid (2012) mengatakan bahwa penyelidikan ilmiah yang dilakukan oleh siswa untuk mencari solusi dari permasalahan dapat mengajak siswa menjadi seorang peneliti yang harus mengumpulkan bukti-bukti ilmiah, mencocokkan dengan literatur yang relevan, dan juga membuat kesimpulan berdasarkan bukti-bukti yang kuat. Chin \& Chia (2005) menambahkan, untuk menemukan solusi, siswa harus mengumpulkan bukti-bukti yang dapat memperkuat jawaban dari permasalahan. Bukti-bukti tersebut dapat mereka temukan melalui internet, wawancara, ataupun eksperimen.

Kegiatan ini dapat melatih siswa untuk menafsirkan bukti ilmiah dan mengidentifikasi bukti tersebut dibalik alasan penarikan kesimpulan. Setelah informasi dan bukti didapatkan, kemudian data dievaluasi. Siswa harus menganalisis, mesintesis, dan mengevalauasi dari setiap kemungkinan jawaban yang ada untuk menemukan solusi. Informasi dan bukti yang didapat siswa kemudian digunakan sebagai dasar untuk membuat kesimpulan berupa solusi dari permasalahan.

Tahap keempat dari $P B L$ adalah mengembangkan dan mempresentasikan artefak dan exhibit. Tahap ini berlangsung pada pertemuan ketiga. Pada tahap ini guru membantu siswa untuk menampilkan hasil penyelidikan mereka 
berupa laporan, foto, rekaman video, dan presentasi kepada orang lain. Setiap kelompok mendapatkan waktu 10 menit untuk mempresentasikan hasil penyelidikan mereka, dilanjutkan dengan diskusi selama 5 menit.

Tahap keempat model $P B L$ sejalan dengan penelitian Savery (2006), yaitu siswa harus dapat menjelaskan kepada teman dan guru bahwa jawaban yang mereka pilih merupakan solusi terbaik, serta meyakinkan bahwa alasan dari kesimpulan yang mereka buat berdasarkan bukti-bukti yang telah mereka kumpulkan. Siswa juga harus menjelaskan keuntungan dan kerugian dari solusi yang diambil. Akcay (2009) menambahkan, karena masalah yang dihadapi merupakan masalah kontekstual dan bersifat ill-structured, maka solusi yang diambil tidak hanya dari satu sudut pandang saja dan harus mempertimbangkan dampak terhadap kehidupan bermasyarakat. Oleh karena itu, tahap ini dapat melatih siswa untuk mengomunikasikan kesimpulan dari solusi yang mereka temukan dan mereflesikan dampak dari perkembangan IPTEK terhadap masyarakat luas.

Tahap kelima model $P B L$ adalah mengevaluasi proses pemecahan masalah. Siswa bersama dengan guru melakukan analisis dan refleksi terhadap proses yang telah digunakan untuk mencari solusi dari permasalahan lingkungan yang ada di sekitar kehidupan mereka. Guru juga melakukan klarifikasi terhadap pertanyaan-pertanyaan siswa yang belum terjawab dan jawabanjawaban siswa yang kurang tepat. Pada tahap ini siswa akan tebentuk konsep dalam benak siswa. Sejalan dengan penelitian Hmelo \& Silver (2004), PBL dapat melatih siswa menjadi pemikir kritis, fleksibel, dan reflektif, yang dapat menggunakan pengetahuan yang dimilikinya untuk mengambil keputusankeputusan penting yang ada dalam kehidupan bermasyarakat. Millar (2008) menambahkan bahwa pengetahuan yang terbentuk selama proses pembelajaran dapat diaplikasikan kepada masalah faktual yang mereka temui, sehingga siswa dapat melatih siswa untuk mengaitkan antara konsep sains dan kejadian nyata, mengetahui alasan dibalik pengambilan keputusan, serta resiko dan kemungkinan yang dihadapi dari keputusan yang diambil.

Selama pembelajaran dengan menggunakan model $P B L$ berbasis potensi lokal berlangsung, siswa bekerja dalam kelompok. Bekerja secara berkelompok dapat membantu siswa untuk meraih nilai yang tinggi jika dibandingkan mereka harus bekerja secara individu. Berdasarkan penelitian Akcay (2009), bekerja dalam kelompok 
membuat siswa lebih aktif berdiskusi dan bertukar pikiran dengan teman dalam kelompok mengenai informasi yang mereka dapatkan, sehingga dapat membantu mereka untuk lebih memahami informasi lebih baik daripada sekedar membaca dari literatur. Choo et. al (2011) dan Yew et. al (2010) menambahkan, bekerja secara berkelompok akan membantu siswa untuk mempelajari konsep dengan lebih baik karena terjadi tukar pikiran antar anggota kelompok, serta dapat membantu siswa mengingat kembali konsep yang telah mereka pelajari.

$P B L$ dapat membantu siswa untuk menemukan sendiri konsep yang akan mereka pelajari. Peran guru hanya sebagai fasilitator yang mengarahkan dan membimbing siswa selama pembelajaran. Sejalan dengan penelitian yang dilakukan oleh Malan et. al (2014), bahwa $P B L$ dapat menuntut siswa menjadi pembelajar mandiri yang harus berperan aktif. Pengetahuan akan dibentuk sendiri oleh siswa melalui pengalaman nyata dengan cara menggabungkan pengetahuan lama yang telah diperoleh dengan informasi-informasi baru yang didapatkan sehingga dapat menciptakan pembelajaran yang bermakna dan pengetahuan akan lebih lama tertanam dalam benak siswa,.
Berdasarkan hasil analisis data menunjukkan bahwa ada pengaruh $P B L$ berbasis potensi lokal terhadap kemampuan literasi sains siswa. Tahapan dalam pembelajaran model $P B L$ berbasis potensi lokal mampu melatih kemampuan literasi sains siswa dalam 4 aspek, yaitu aspek mengidentifikasi isu ilmiah, menjelaskan fenomena secara ilmiah, dan menggunakan bukti ilmiah.

\section{Kesimpulan}

Berdasarkan hasil penelitian tentang pengaruh model $P B L$ berbasis potensi lokal terhadap kemampuan literasi sains siswa kelas X SMA Negeri 1 Cepogo Tahun Pelajaran 2013/2014 dapat disimpulkan terdapat pengaruh model $P B L$ berbasis potensi lokal terhadap peningkatan kemampuan literasi sains siswa kelas X SMA Negeri 1 Cepogo. Rata-rata aspek tertinggi pada kelas eksperimen adalah aspek menggunakan bukti ilmiah,sedangkan aspek terendah adalah mengidentifikasi isu ilmiah.

\section{Daftar Pustaka}

Akcay, B. (2009). Problem-Based Learning in Science Education. Journal of Turkish Science Education, 6 (1), 2636

Arends, R.I. (2008). Belajar untuk Mengajar. Edisi Ketujuh/Buku Dua. Terj. Helly Prajitno Soetjipto. Yogyakarta: Pustaka Belajar 
Chin, C., and Chia, L.G. (2005). Problem-Based Learning: Using IllStructured Problems in Biology Project Work. Wiley Periodicals, Inc

Choo, S. S. Y., et al. (2011). Effect of Worksheet Scaffolds on Student Learning in Problem-Based Learning. Adv in Health Sci Educ, 16 (2), 517528

Dahar, R. W. (2011). Teori-Teori Belajar dan Pembelajaran. Jakarta: Erlangga

Dani, D. (2009). Scientific Literacy and Purposes for Teaching Science: A Case Study of Lebanese Private School Teachers. International Journal of Environmental \& Science Education, 4 (3), 289-299. Editor Richard K \& Neil Taylor. Turki: Abant Ixxet Baysal University

Hmelo, C.E., Silver. (2004). ProblemBased Learning: What and How Do Students Learn?. Educational Psychology Review, 16 (3), 225-266

Hung, W., Jonassen, D.H., Liu, R. (2008). Problem Based Learning. In J. communications and technology (3rd ed., pp. 485-506).

Liu, X. (2009). Beyond science literacy: Science and the Public. International Journal of Environmental \& Science Education, 4 (3), 301-311

Malan, S.B., Ndlovu, M., Engelbrecht. (2014). Introducing Problem-Based Learning (PBL) Into a Foundation Programme to Develop Self-Directed Learning Skills. South African Journal of Education, 34(1), 1-16

Maurer, H., Neuhold, C. (2012)._Problems Everywhere? Strengths and Challenges of a Problem-Based Learning Approach in European Studies. Higher Education Academy Social Science Conference "Ways of Knowing, Ways of Learning”. 28-29 Mei 2012. Liverpool.

Millar, R. (2008). Taking Scientific Literacy Seriously as a Curriculum Aim. Asia-Pacific Forum on Science Learning and Teaching, 9 (2), 1-18
Mumpuni, K.E. (2013). Potensi Pendidkan Keunggulan Lokal berbasis Karakter dalam Pembelajaan Biologi di Indonesia. Seminar Nasional $X$ Pendidikan Biologi, hlm 1-7. Surakarta: FKIP Universitas Sebelas Maret

Organisation for Economic Co-operation and Development. (2009). PISA 2009 Assessment Framework, Key Competences in Reading, Mathematic and Science.

Preczewski, P.J., Mittler, A., Tillotson, J.W. (2009). Perspectives of German and US Students as They Make Meaning of Science in Their Everyday Lives. In Richard, K. \& Taylor, N. International Journal of Environmental \& Science Education, 4 (3), 247-258. Turki: Abant Ixxet Baysal University.

Santoso, A.M. (2010). Konsep Diri Melalui Pendidikan Berbasis Keunggulan lokal sebagai Model Pendidikan Berkarakter dan Berbudaya Bangsa Di Era Global. Proceedings of the 4th International Conference on Teacher Education, hlm 477-486. Bandung: Universitas Pendidikan Indonesia

Savery, J.R. (2006). Overview of Problem-based Learning: Definitions and Distinctions. Interdisciplinary Journal of Problem-based Learning, 1, 9-20

Suastra. I.W (2005). Merekonstruksi Sains Asli (Indigenous Science) dalam Upaya Mengembangkan Pendidikan Sains Berbasis Budaya Lokal di Sekolah. Jurnal Pendidikan dan Pengajaran IKIP Negeri Singaraja, 38 (3), 377-396

(2010). Model

Pembelajaran Sains berbasis Budaya Lokal untuk Mengembangkan Kompetensi Dasar Sains dan Nilai Kearifan Lokal di SMP. Jurnal Pendidikan dan Pengajaran, 43 (2), 816

Toharudin, U., Hendrawati, S., Rustaman, A. (2011). Membangun Literasi Sains Peserta Didik. Bandung: Humaniora. 
Yew, E. H. J. \& Schmidt, H. G. (2009). Evidence for Constructive, SelfRegulatory, and Collaborative Process in Problem-Based Learning. Adv in Health Sci Educ, 14 (2), 251-273
Yew, E.H.J., Chng, E., Schmidt, H.G. (2011). Is learning in problem-based learning cumulative?. Adv in Health Sci Educ, 16 (2), 449-464 